\title{
Mercury Influences Uptake of Amino Acids by Marine Bacteria
}

\author{
D. Siebers ${ }^{1}$, M. Hoppenheit ${ }^{2}$, and U. Harms ${ }^{3}$ \\ 1 Biologische Anstalt Helgoland, Zentrale, Palmaille 9, D-2000 Hamburg 50, Federal Republic of Germany \\ 2 Biologische Anstalt Helgoland, Isotopenlabor, Wüstland 2, D-2000 Hamburg 55, Federal Republic of Germany \\ ${ }^{3}$ Bundesforschungsanstalt für Fischerei, Isotopenlabor, Wüstland 2, D-2000 Hamburg 55, Federal Republic of Germany
}

\begin{abstract}
Natural multispecies bacterial communities, in a resting state and at low initial densities, were used to study effects of dissolved mercury on nutrient absorption. Nutrients were offered as $10 \mu \mathrm{M}$ amino-acid mixture, in the relative proportions encountered in natural sea-water samples. Uptake, commencing after an initial stationary phase, resulted from induction of transport mechanisms in a relatively constant number of bacteria, rather than from increased densities due to multiplication following nutrient availability. The periods elapsed to reduce ambient amino-acid concentrations to half of the initially present levels were greatly influenced by the presence of low levels of $\mathrm{Hg}$, revealing significant uptake inhibition at a sensitivity threshold of $0.625 \mu \mathrm{g} \mathrm{l^{-1 }} \mathrm{Hg}$. Low $\mathrm{Hg}$ levels affected induction and uptake in dormant bacteria, but had no effect on uptake in a high density community in the logarithmic phase. Higher levels of up to $488 \mu \mathrm{g} \mathrm{l^{-1 }} \mathrm{Hg}$ greatly decreased rates of uptake and prolonged the duration of lag phases, obviously due to changes in species composition. Use of natural multispecies communities allowed the simultaneous quantitative detection of a sequence of different $\mathrm{Hg}$ levels, varying from lowest $(0.625)$ to highest $\left(488 \mu \mathrm{g} \mathrm{I}^{-1} \mathrm{Hg}\right)$ ambient concentrations. Initially present levels of total $\left(2.5 \mu \mathrm{g} \mathrm{l}^{-1}\right)$ and dissolved $\mathrm{Hg}$ decreased rapidly, while mercury associated with the particulate material increased to constant values between 12 and $16 \mathrm{~h}$ after the start of experiments. Our findings indicate that toxicity is less due to concentration of $\mathrm{Hg}$ alone, but rather depends on the relation between concentration and biomass. Because of unavoidable changes in sea-water properties resulting from handling between sampling and start of the tests (transport, storage and freeing of collected samples from originally present bacteria), the procedure is probably not appropriate for detecting subtle differences in water quality present in the sea at dumping sites and in adjacent polluted areas.
\end{abstract}

\section{INTRODUCTION}

A major contribution of marine ecology to the process of political decision making in the field of protection and conservation of environmental health is concerned with the evaluation of sea water quality. Analytical approaches must provide data to identify the state of coastal and offshore sea water in terms of its capacity to support indigenous aquatic life.

Physical and chemical techniques for analyzing abiotic environmental factors, including individual noxious components, are usually more sensitive than procedures using living organisms. Test organisms, on the other hand, are capable of responding to the sum of environmental components. In many cases organisms which are easy to cultivate and have limited ecological significance are used in toxicological studies. More attention should be paid to ecological key species, preferably with high sensitivities to the pollutants concerned. For a number of marine animals a synopsis of sensitivities in terms of differences in acute toxicities of zinc, copper and mercury has been presented by Karbe (1972); a list of marine species which are, or potentially may be, used for bioassaying seawater samples has been compiled by Stebbing et al. (1980).

In all cases investigated, free-swimming larvae of marine invertebrate and fish species, when compared 
to adults, have revealed increased sensitivities to a large variety of contaminants. Hence, planktonic oyster and sea urchin larvae - in addition to the unicellular alga Skeletonema costatum - constitute important bioassay organisms (Okubo and Okubo, 1962; Kobayashi, 1971; Woelke, 1972; Calabrese et al., 1973; Jensen et al., 1974; Cardwell et al., 1977; Stebbing et al., 1980)

\section{MATERIALS AND METHODS}

\section{Analytical Set Up}

We exposed mixed natural bacterial strains in a dormant state to different mercury levels. In order to assess the activity of the bacteria, we determined their capacity for taking up organic nutrients. The dissolved substances offered consisted of a mixture of 16 amino acids. In this mixture (Siebers, 1979), the relative proportions of individual amino acids resembled the compositions encountered in sea water obtained from different localities in North Sea (Bohling, 1972) and Baltic Sea (Dawson and Pritchard, 1978).

Experiments ( $\mathrm{n}=4-8$ ) were performed in a seawater $(35 \% \mathrm{~S})$ volume of $50 \mathrm{ml}$, contained in unstoppered Erlenmeyer flasks, agitated by means of a rotary shaker (Infors, Basel) at $150 \mathrm{rpm}$. A small volume of a concentrated amino-acid mixture was added in order to obtain the initial concentration of $10 \mu \mathrm{M}$. Following a lag phase, amino acids were, due to bacterial net uptake, reduced to lower concentrations. Aliquots of 1 $\mathrm{ml}$ were taken at zero time, followed by sampling every morning and evening yielding immediate information on the duration of the lag phase. After microbial uptake had commenced, samples were taken at regular intervals of 4,8 , or $12 \mathrm{~h}$, transferred to reagent vials, sealed with parafilm, and stored deep frozen at $-25^{\circ} \mathrm{C}$. The experiments were terminated, when the nutrients offered had been consumed

In order to estimate the amount of total amino acids in the samples collected, these were allowed to attain room temperature. Fluorescent amino-acid derivatives were prepared according to Udenfried et al. (1972), North (1975), and Stephens (1975). They were measured by means of an Aminco fluorimeter against a blank and the initially added amino-acid concentration of $10 \mu \mathrm{M}$ as standard. We did not investigate the potential contribution to fluorescence by cells or amino acids released from cells due to deep freezing. This contribution is assumed to be small, because blanks (sea water of low bacterial activity) did not differ significantly from samples taken after all initially added amino acids had been consumed.

\section{Source of Sea Water and Heterotrophic Bacteria}

The sea water used was collected near Helgoland (Southern North Sea) and aged for several months at room temperature in dark, non aerated tanks. Portions of this water were transferred to a 30-l aquarium; here the water was aerated and passed over a $2-3 \mathrm{~mm}$ gravel filter of 11 volume for at least 2 weeks prior to use. The 30-l aquarium was in use throughout the year. The water was partially renewed every second week after reducing the initial volume of 301 by about 31 . The light was dimmed, and no nutrients or organisms were added. The water was virtually free of phytoplankton cells, protozoans and bacterial colonies fixed to particles. Heterotrophic bacteria in the gravel filter may have been responsible for the fact that no dissolved carbohydrates or amino acids were detectable. A very low, but relatively constant number of $600 \pm 200$ colonies $\mathrm{ml}^{-1}$ was found within a few days after spreading this water on agar plates. Hence, the sea water used for describing bacterial sensitivities to mercury was already inhabited by the test organisms. We refer here to this water as 'sea water of low bacterial activity'; it was always used for starting our experiments.

\section{Application and Quantification of Mercury}

Mercury was applied as $\mathrm{HgCl}_{2}$ (Merck) in distilled water from a concentrated solution. Once used, Erlenmeyer flasks were individually marked to ensure that they were re-employed for the same concentration.

Mercury was determined by the cold vapor atomic absorption method (Olafsson, 1974; Harms, 1979) in a test series performed in the absence and the presence of $2.5 \mu \mathrm{g} \mathrm{l^{-1 }} \mathrm{Hg}$.

\section{Counting of Bacteria}

One test series examined the development of bacterial densities. Colonies were counted on agar plates 2216 E (Gunkel and Rheinheimer, 1968). To control sterility the plates were stored for 4 weeks at $15^{\circ} \mathrm{C}$ in the dark. Test samples of $100 \mu 1$ were spread over agar plates. At zero time dilution was not necessary, but samples taken later had to be diluted up to $1: 10^{3}$ before spreading. Only plates which had $50-150$ bacterial colonies after storage at $15^{\circ} \mathrm{C}$ in the dark for 3 weeks were taken into consideration. 


\section{Bioassays}

In order to test the applicability of bacterial aminoacid uptake as a means to bioassay sea-water samples, it was necessary to remove bacteria; these may differ in density, species composition and physiological state. Such removal, however, should not influence the original potential degree of toxicity Thereafter the samples could be inoculated with identical amounts of bacteria contained in equal volumes of sea water of low bacterial activity.

The samples were pasteurized twice for 12 h at $80^{\circ} \mathrm{C}$ with an interlude of $12 \mathrm{~h}$ at $15^{\circ} \mathrm{C}$ by heating $250 \mathrm{ml}$ in closed (screw caps) polyethylene bottles. A series of independent tests demonstrated that pasteurization at $80^{\circ} \mathrm{C}$ resulted in sterilization of the media. Prior to the start of the experiment, $45 \mathrm{ml}$ were shaken overnight to saturate the medium with oxygen. The next morning the assays were started by addition of $5 \mathrm{ml}$ of sea water of low bacterial activity and $10 \mu \mathrm{M}$ of the amino-acid mixture. In order to establish a mercury scale for comparison and quantification of bacterial uptake response, 4 different concentrations of $\mathrm{Hg}(5,15,45$, $135 \mu \mathrm{g} \mathrm{l}^{-1} \mathrm{Hg}$ ) were employed.

Several other methods tried had to be rejected. Autoclaving of sea water $\left(121^{\circ} \mathrm{C}, 1 \mathrm{~atm}, 20 \mathrm{~min}\right)$ resulted in the formation of precipitates, which could not be redissolved by stirring for $12 \mathrm{~h}$ at $15^{\circ} \mathrm{C}$ and introduced considerable negative effects; these manifested themselves in a retardation of amino-acid absorption. Ultracentrifugation at $10-15000 \mathrm{~g}$ for $30 \mathrm{~min}$ at $4{ }^{\circ} \mathrm{C}$ was not regarded safe enough to quantitatively exclude bacteria; we could not control whether or not some of them might have loosened from the pellets and might thus have been transferred to the test flasks. Ultrafiltration was not taken into consideration because of probable influence on water quality due to interference of filter materials with toxicants (cf. Kurtz, 1977).

\section{Statistical Treatment of Data}

The basic information was provided by measurements of the reduction of amino acids from $10 \mu \mathrm{M}$ to zero levels in relation to time as a result of bacterial uptake. As the $50 \%$ endpoint of a response is less influenced by chance variations than any other (cf. Reed and Muench, 1938), the period to reach $50 \%$ degradation or uptake of amino acids has been taken as the measure of the effects of $\mathrm{Hg}$ added to the test medium. The period is referred to as the 'time lag (h)' for $50 \%$ amino-acid uptake. The $50 \%$ endpoints were estimated from interpolations performed by means of the cubic spine function (cf. Wold, 1974), the single term exponential function and its inversion. In some cases a straight line could or had to be used. Visual inspection of plotted data and function and the achieved degree of fit served as criteria for selecting the interpolation procedure. The number of aminoacid levels which could be included in the interpolation procedure varied between 3 and 8 , depending on sampling interval, rate of uptake, and function chosen. In the majority of cases preference was given to the cubic spline fit. Several functions describing nonlinear relationships were found to yield similar estimates. Thus, the choice of the interpolation procedure seems to be uncritical with respect to the bias produced. Nevertheless, the possibility should be taken into account that the probability level gained in a statistical analysis can be affected by the interpolation procedure. Especially in the case of small differences between neighbouring groups, wrong conclusions can be drawn.

The relationship between the estimated $50 \%$ degradation of amino acids and the concentration of added Hg was found to follow the general model of a multiple term exponential function

$$
y=a_{1}+a_{1} e^{h}+\quad+a_{1} e^{h} j^{\prime \prime}
$$

The iterations revealed that the variation of the $50 \%$ endpoint with the $\mathrm{Hg}$-concentrations applied can adequately be described by a single or double term function.

Means of estimated time lags as a result of different $\mathrm{Hg}$ concentrations were compared by analyzing the variance for a one-way classification. Bartlett's test was applied to prove the equality of variances. The evaluation of data was largely facilitated and enhanced by available statistic software.

\section{RESULTS}

\section{Influence of Mercury on Heterotrophic Amino-Acid Absorption}

Bacterial amino-acid uptake in the absence and in the presence of varying concentrations of mercury commences after a lag phase, during which no measurable absorption takes place (Fig. 1). The lag phases are prolonged by increasing concentrations of mercury Uptake follows an S-shaped curve, in which the presence of higher mercury levels markedly decreases the slope. When the time lag for $50 \%$ amino-acid reduction - note the difference between 'lag phase, during which no measurable absorption takes place' (stationary phase) and time lag for a $50 \%$ amino-acid reduction' - is plotted against Hg concentration (Fig. 2), a single term exponential function can be fitted to the 


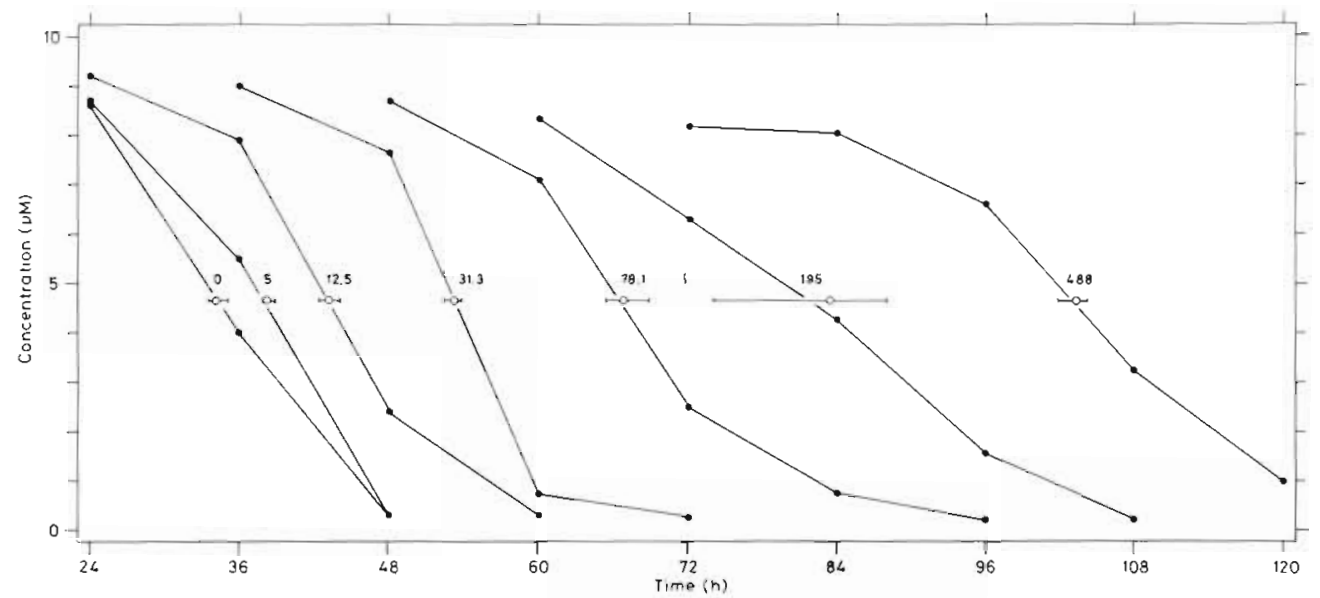

Fig. 1. Heterotrophic amino-acid uptake as a function of ambient $\mathrm{Hg}$ concentration $\left(0-488 \mu \mathrm{g} \mathrm{l^{-1 }} \mathrm{Hg}\right)$. Closed circles: means of 4 replicates; open circles and horizontal bars: estimated means and ranges of time elapsed to reach $50 \%$ of initial amino-acid concentrations (i.e. $9.3 \pm 0.4 \mu \mathrm{M}$, determined $12 \mathrm{~h}$ after start of experiment)

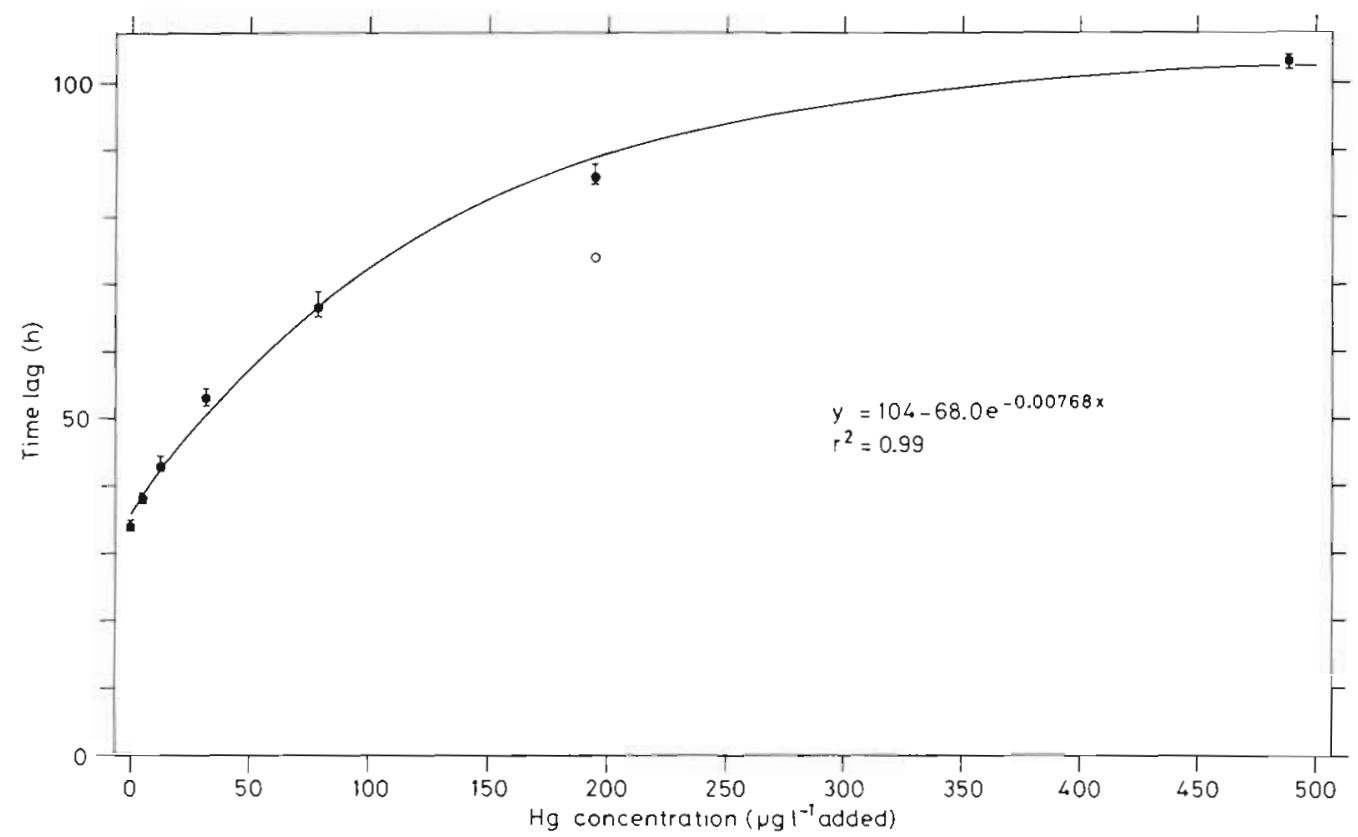

Fig. 2. Time lag for achieving $50 \%$ initial amino-acid concentration versus Hg concentration. Closed circles and vertical bars: estimated means and ranges of 4 replicates each; open circle: outlier. Same experiment as in Fig. 1

data with a high value for $r^{2}$. The levels differ highly significantly from each other $(a<0.0001)$.

To test smaller concentration ranges of mercury, levels of $2.5-80 \mu \mathrm{g} \mathrm{l}^{-1} \mathrm{Hg}$ were applied and compared to controls (Figs. 3-6). The biphasic course of the plot of time for $50 \%$ uptake against the $\mathrm{Hg}$ concentration (Fig. 4) can be described by a double term exponential function, indicating that more than one bacterial strain is included in the experiment. This interpretation is supported by experimental runs of the populations exposed to $80 \mu \mathrm{g} \mathrm{l}^{-1} \mathrm{Hg}$. An example is presented by plotting the attained amino-acid levels against time
(Fig. 5). Fig 6 presents a sector of data of Fig. 4 to which a single term exponential function can be fitted. In order to exclude results from communities with differential sensitivities to $\mathrm{Hg}$ - which are incomparable by one-way classification - only data were included in the analysis which follow a single exponential process. Since mixed populations may behave like single species populations (Bick, 1964), the term community is preferred in the present context. The controls differ significantly from communities exposed to 5 and $10 \mu \mathrm{g}$ $\mathrm{l}^{-1} \mathrm{Hg}(\alpha<0.01)$. The difference between exposures to 2.5 and $5 \mu \mathrm{g} \mathrm{I}^{-1} \mathrm{Hg}$ is significant at the $5 \%$ level. 


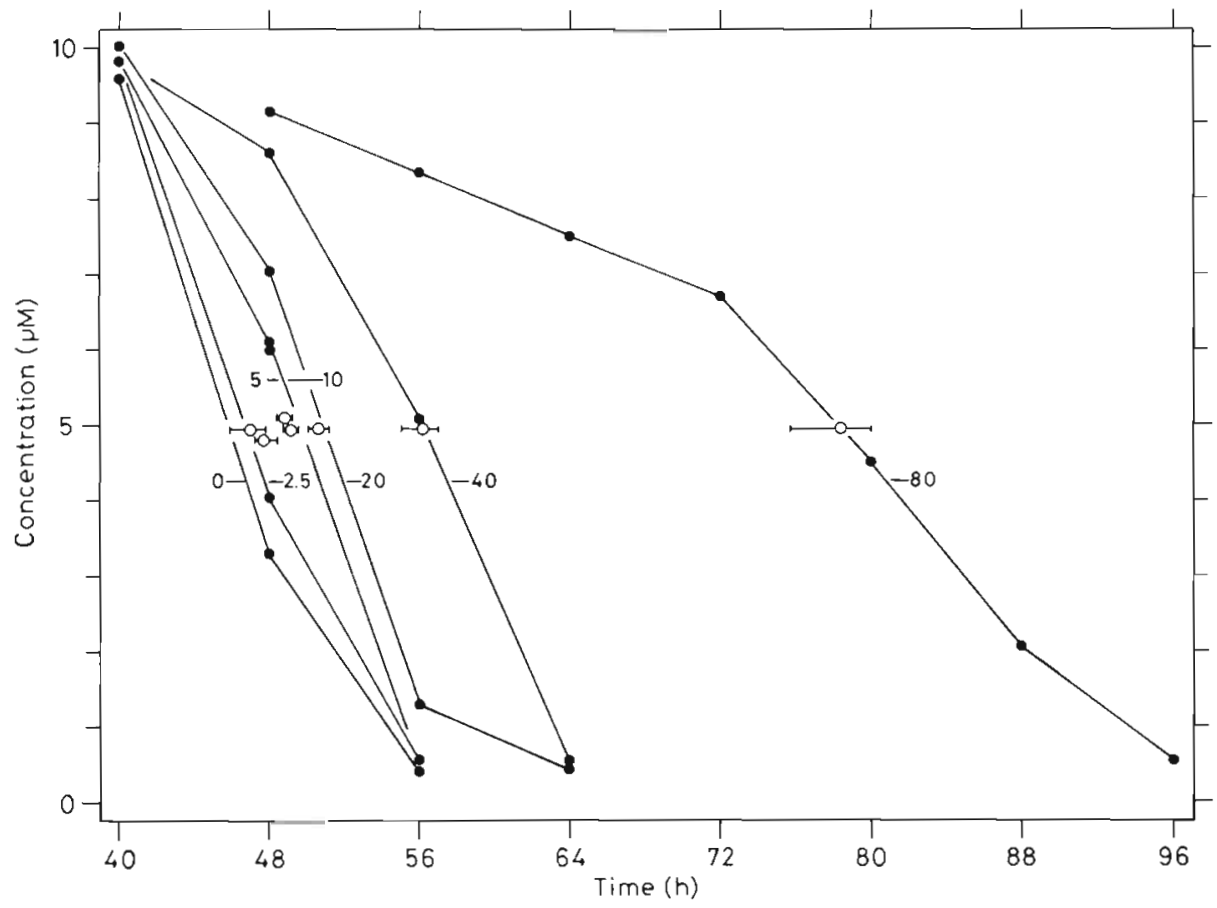

Fig. 3. Heterotrophic amino-acid uptake as a function of ambient $\mathrm{Hg}$ concentration $\left(0-80 \mu g \mathrm{I}^{-1} \mathrm{Hg}\right)$. Closed circles: means of 5 replicates; open circles and horizontal bars: estimated means and ranges of time elapsed to reach $50 \%$ of initial amino-acid concentrations (i.e. $9.9 \pm 0.5 \mu \mathrm{M}$, determined $40 \mathrm{~h}$ after start of experiment)

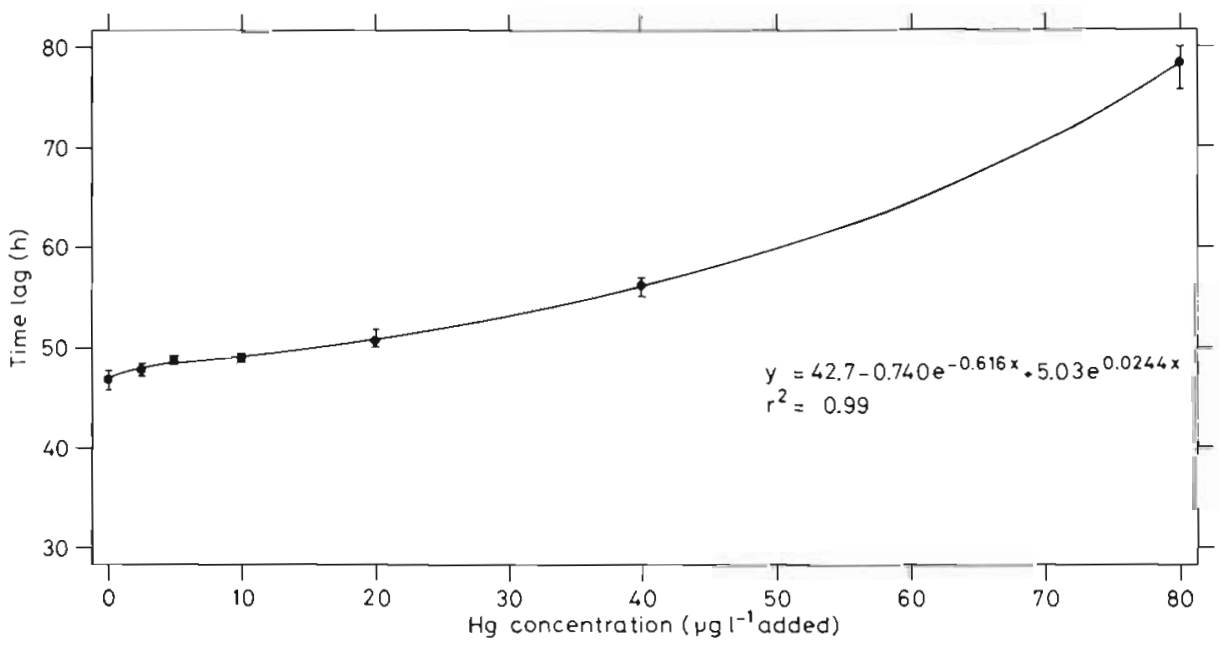

Fig. 4. Time lag for achieving $50 \%$ initial amino-acid concentration versus $\mathrm{Hg}$ concentration. Closed circles and vertical bars: estimated means and ranges of 5 replicates each. Same experiment as in Fig. 3

To increase the probability of detecting true differences in responses to a series of low and only slightly varying concentrations of mercury, the number of runs per level was enlarged to 8 (Figs. 7, 8). Again, analysis of variance was restricted to groups which seemingly belong to the same community (Levels $0,2.5,5$, and 10 $\mu \mathrm{g} \mathrm{l}^{-1} \mathrm{Hg}$ in Fig. 8). For the differences between groups an $a<0.001$ was found. The lowest tested concentrations to affect nutrient absorption were 0.625 and 1.25 $\mu \mathrm{g} \mathrm{l}^{-1} \mathrm{Hg}$ (Figs. 9, 10). Means of time lags for $50 \%$ uptake at levels of 0 to $5 \mu \mathrm{g} \mathrm{l^{-1 }} \mathrm{Hg}$ were compared by analysis of variance, yielding significant differences between the 0.625 and the neighbouring levels of 0 $(\alpha<0.01)$ and $1.25 \mu \mathrm{g} \mathrm{l}^{-1} \mathrm{Hg}(\alpha<0.001)$.

When parallel to amino-acid uptake (Fig. 11), bacterial development in terms of densities (Fig. 12) was analyzed in the same populations, no differences in cell numbers representing growth and multiplication 


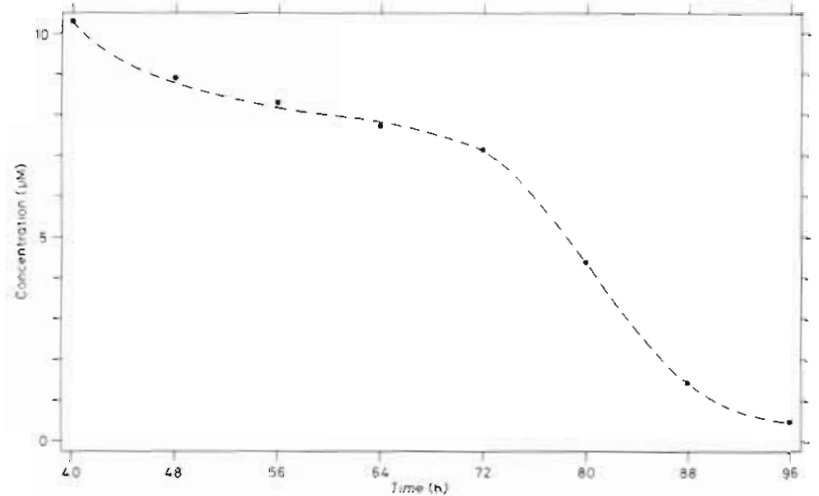

Fig. 5. Heterotrophic amino-acid uptake in a test medium treated with $80 \mu \mathrm{g} I$ ' $\mathrm{Hg}$. Closed circles: amino-acid concentrations in a single experimental run (c.f. Fig. 3). Eye fitted curve

were evident between controls and communities exposed to $10 \mu \mathrm{g} \mathrm{l}^{-1} \mathrm{Hg}$. While amino-acid absorption was susceptible to the presence of $10 \mu \mathrm{g} \mathrm{l}^{-1} \mathrm{Hg}$ (Fig. 11), growth did not show such susceptibility. To calculate doubling times, data obtained from controls and communities exposed to $10 \mu \mathrm{g} \mathrm{l}^{-1} \mathrm{Hg}$ could therefore be pooled. The doubling times were initially $5 \mathrm{~h}$ (16-28 h); they increased to maximum values of 2.4 h (28-40), and decreased thereafter to $4.1 \mathrm{~h}(40-56 \mathrm{~h})$.

In the present case, the initial amino-acid concentration of $10 \mu \mathrm{M}$ is the exact amount of organic material to produce a final density of about $1.6 \quad 10^{\prime \prime}$ bacterial cells $\mathrm{ml}^{-1}$. That means, about $6 \cdot 10^{-15}$ moles of amino acids constituted the nutritive basis for 1 cell in these experiments.
Within the series of experiments analyzing the effects of $0.625-10 \mu g ~^{-1} \mathrm{Hg}$ (Figs. 9. 10), samples were taken from communities exposed to $2.5 \mu \mathrm{g} \mathrm{l} 1 \mathrm{Hg}$ in order to determine total and dissolved mercury (Fig 13). While unprocessed sea water served for determining total $\mathrm{Hg}$, data for dissolved $\mathrm{Hg}$ were obtained from samples having passed a $0.22 \mu \mathrm{m}$ Millipore filter. Data for mercury associated with the particulate fraction were obtained from the differences between total and dissolved amounts. Total mercury and the dissolved fraction decreased rapidly, while mercury associated with particulate material - presumably microbial cells - increased to constant values between 12 and $16 \mathrm{~h}$ after the start. Thereafter, rates of decrease of total and dissolved $\mathrm{Hg}$ increased.

The initial stationary phases in communities exposed to $0-10 \mu \mathrm{g}^{-1} \mathrm{Hg}$ (Fig. 9) lasted about $28 \mathrm{~h}$. As the amounts of mercury associated with the particulate materials reached maximum values after $12 \mathrm{~h}$ (Fig. 13), the concentration of dissolved $\mathrm{Hg}$ was reduced to a value of $0.3 \mu \mathrm{g} \mathrm{l}^{-1}$ after $28 \mathrm{~h}$, and growth could not be recognized until about $16 \mathrm{~h}$ after the start of the experiments (cf. Fig. 12), it can be concluded that $\mathrm{Hg}$ at low concentrations affects the initial processes of nutrient recognition, induction and uptake rather than the subsequent process of growth.

The initial concentrations of mercury can only have affected a small number of about 600 bacterial cells $\mathrm{ml}^{-1}$ found in the inoculum. Retardations of amino-acid uptake could not be observed in experiments performed in the presence of $2.5,5$, and $10 \mu \mathrm{g} l^{\prime} \mathrm{Hg}$ during exponential growth of a much denser bacterial population (results not presented in detail). Therefore toxicity

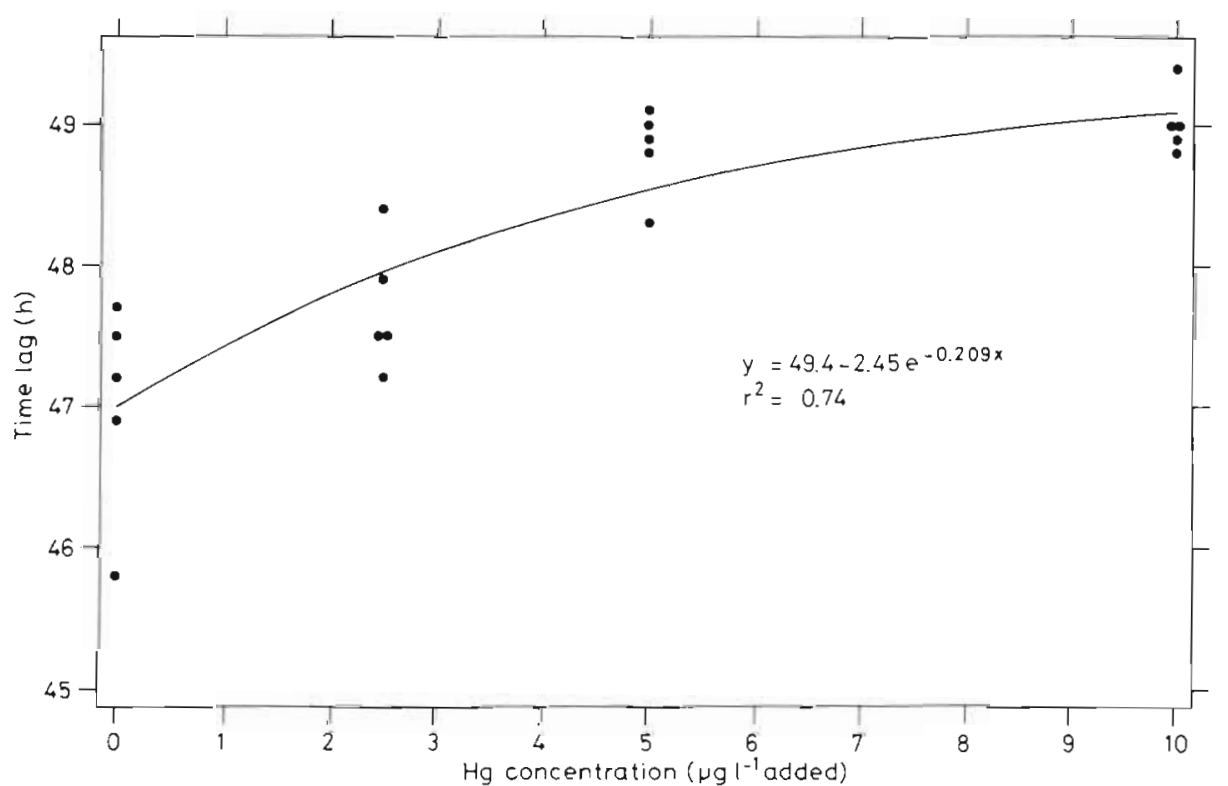

Fig. 6. Time lag for achieving $50 \%$ inilial amino-acid concentration versus Hg concentration. Same data as in Fig. 4 


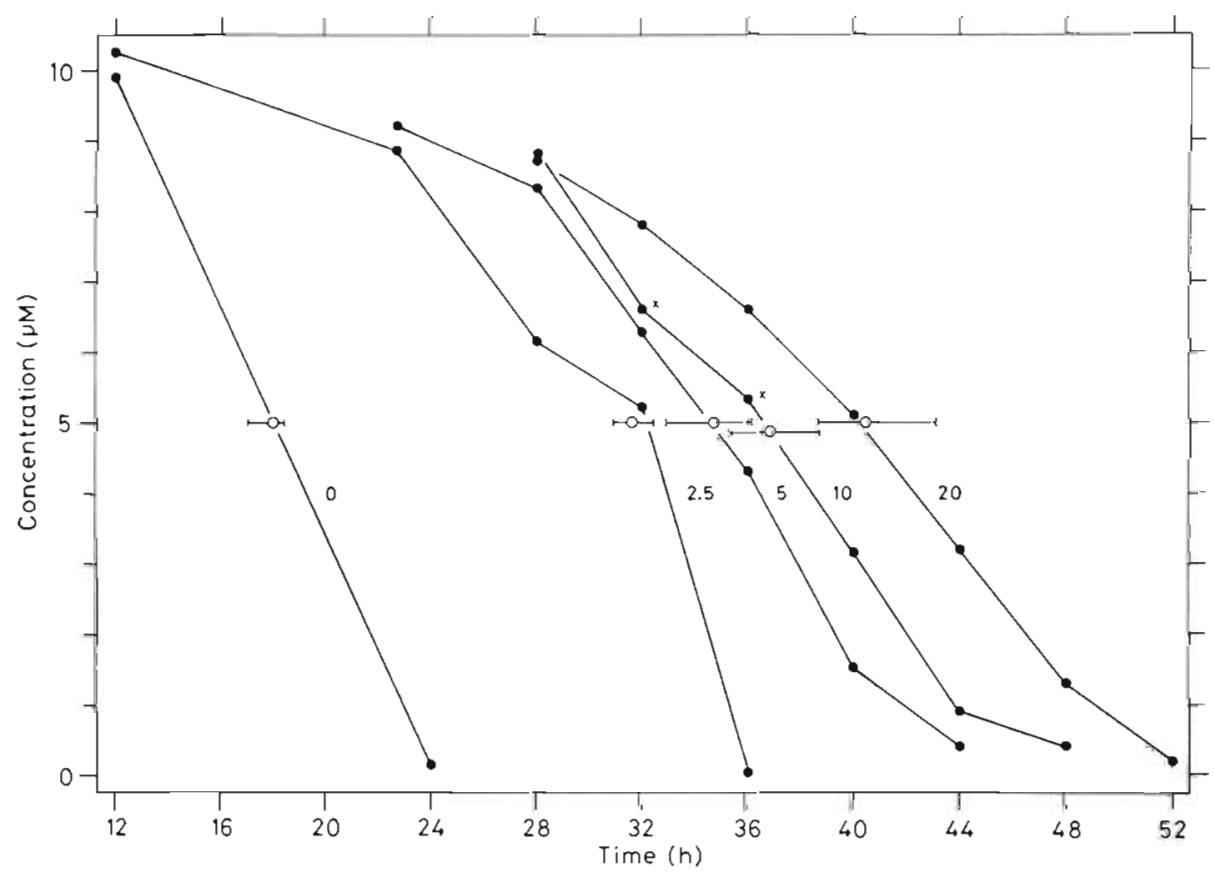

Fig. 7. Heterotrophic amino-acid uptake as a function of ambient $\mathrm{Hg}$ concentration $\left(0-20 \mu g \mathrm{l}^{-1} \mathrm{Hg}\right)$. Closed circles: means of 8 replicates; open circles and horizontal bars: estimated means and ranges of time elapsed to reach $50 \%$ of initial amino-acid

concentrations (i.e. $10.0 \pm 0.6 \mu \mathrm{M}$, determined $12 \mathrm{~h}$ after start of experiment). Crosses: elimination of 2 outliers each

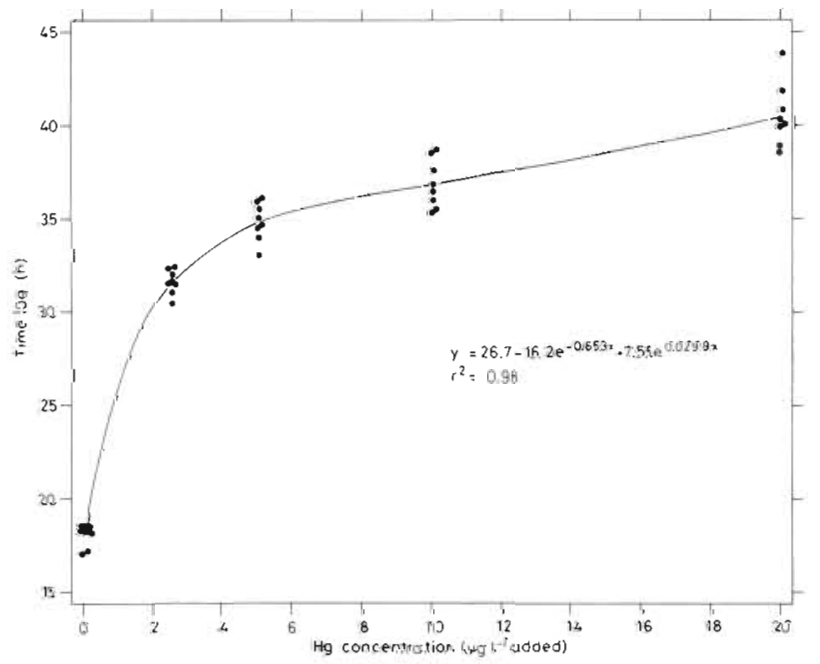

Fig. 8. Time lag for achieving $50 \%$ initial amino-acid concentration versus $\mathrm{Hg}$ concentration. Same experiment as in Fig. 7

cannot be considered to depend on concentration alone, but rather on the relation of contaminant concentration in a water sample to biomass.

\section{Bioassays}

In order to test bacterial amino-acid uptake as a potential means of bioassaying different sea-water samples, it was necessary to investigate the fate of mercury during the procedure which had to be employed to sterilize these samples $\left(2 \times 12 \mathrm{~h}\right.$ at $80^{\circ} \mathrm{C}$ with an interruption of $12 \mathrm{~h}$ at $15^{\circ} \mathrm{C}$, followed by agitation for ca $12 \mathrm{~h}$ at $15^{\circ} \mathrm{C}$ ). A test series of samples which had received additions of 5, 15, 45 and $135 \mu \mathrm{g} \mathrm{l}^{-1}$ $\mathrm{Hg}$ prior to pasteurization was compared to a series of samples receiving additions of mercury following sterilization, shortly before starting the experiment (Fig. 14) by adding of $10 \%$ of unprocessed sea water of low bacterial activity. The unpolluted controls contained pasteurized sea water. The results obtained clearly demonstrate that the samples which had received $\mathrm{Hg}$ following pasteurization significantly differ from controls and among each other. However, samples containing concentrations of 5,15 , and $45 \mu \mathrm{g}$ $1^{-1} \mathrm{Hg}$ added prior to pasteurization did not differ from controls and among each other. The concentration of $135 \mu \mathrm{g} \mathrm{l}^{-1} \mathrm{Hg}$ had been reduced to a toxicity comparable to $45 \mu \mathrm{g} \mathrm{l}^{-1} \mathrm{Hg}$, showing that roughly $90 \mu \mathrm{g} \mathrm{l}^{-1} \mathrm{Hg}$ had been lost during pasteurization.

\section{DISCUSSION}

\section{Heterotrophic Absorption of Amino Acids}

With respect to the S-shaped uptake observed and the increasing bacterial densities in the course of the tests (Fig. 12), it is obvious that heterotrophic bacteria are responsible for the decrease in amino-acid levels 


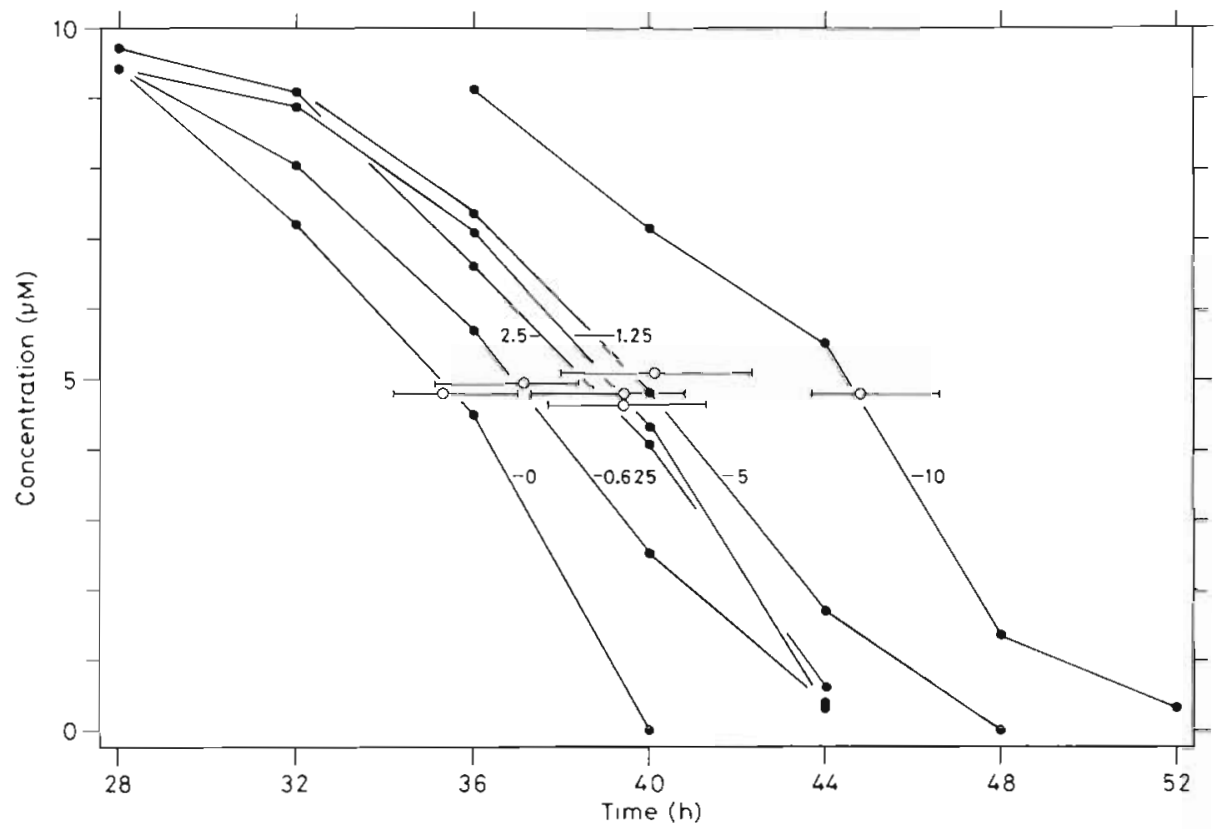

Fig. 9. Heterotrophic amino-acid uptake as a function of ambient $\mathrm{Hg}$ concentration (0-10 $\left.\mathrm{pg})^{\prime} \mathrm{Hg}\right)$. Closed circles: means of 8 replicates; open circles and horizontal bars: estimated means and ranges of time to reach $50 \%$ of injtial amino-acid concentrations (i.e. $9.6 \pm 0.2 \mu \mathrm{M}$, determined $24 \mathrm{~h}$ after start of experiment)

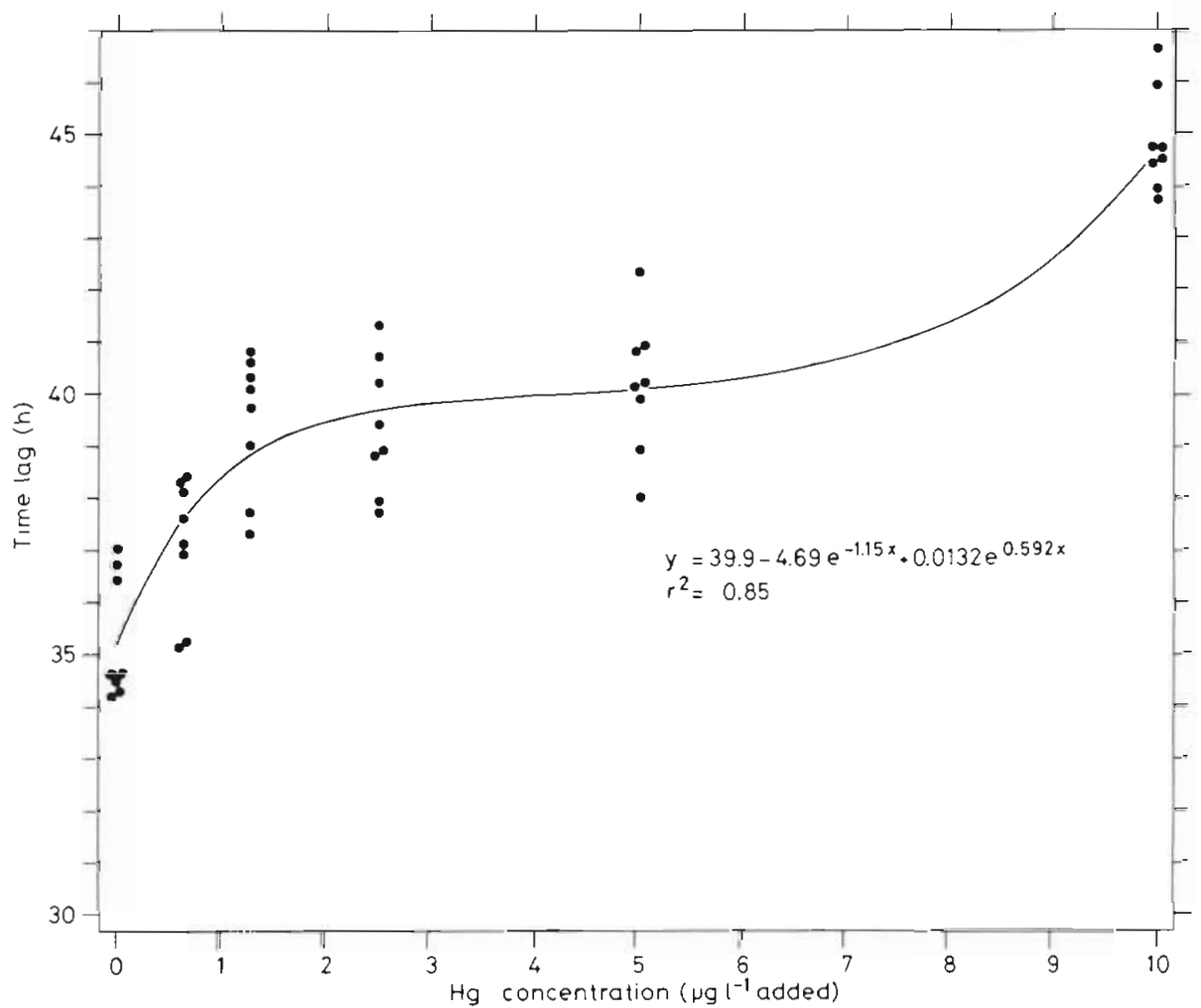

Fig. 10. Time lag for acheving $50 \%$ initial amıno-acid concentration versus Hg concentration 


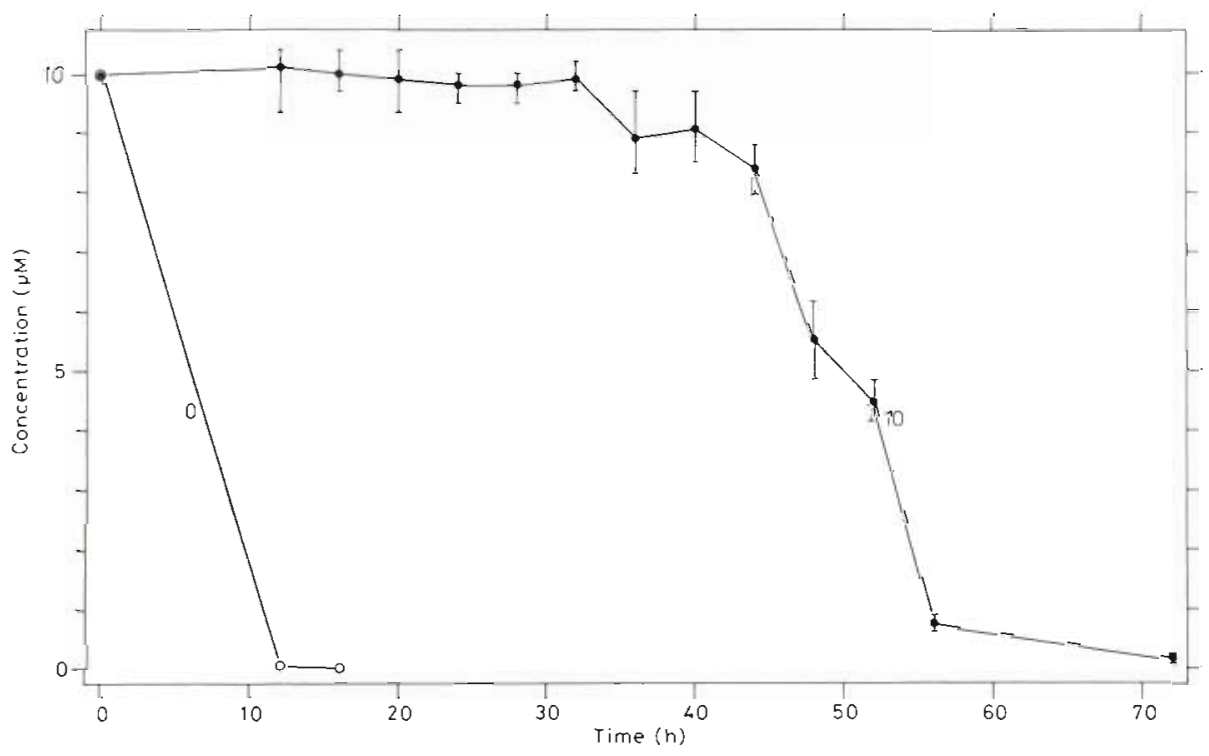

Fig. 11. Heterotrophic amino-acid uptake as a function of ambient $\mathrm{Hg}$ concentration (0 and $\left.10 \mu \mathrm{g} \mathrm{l^{-1 }} \mathrm{Hg}\right)$. Circles: estimated means of 4 replicates; vertical bars: ranges

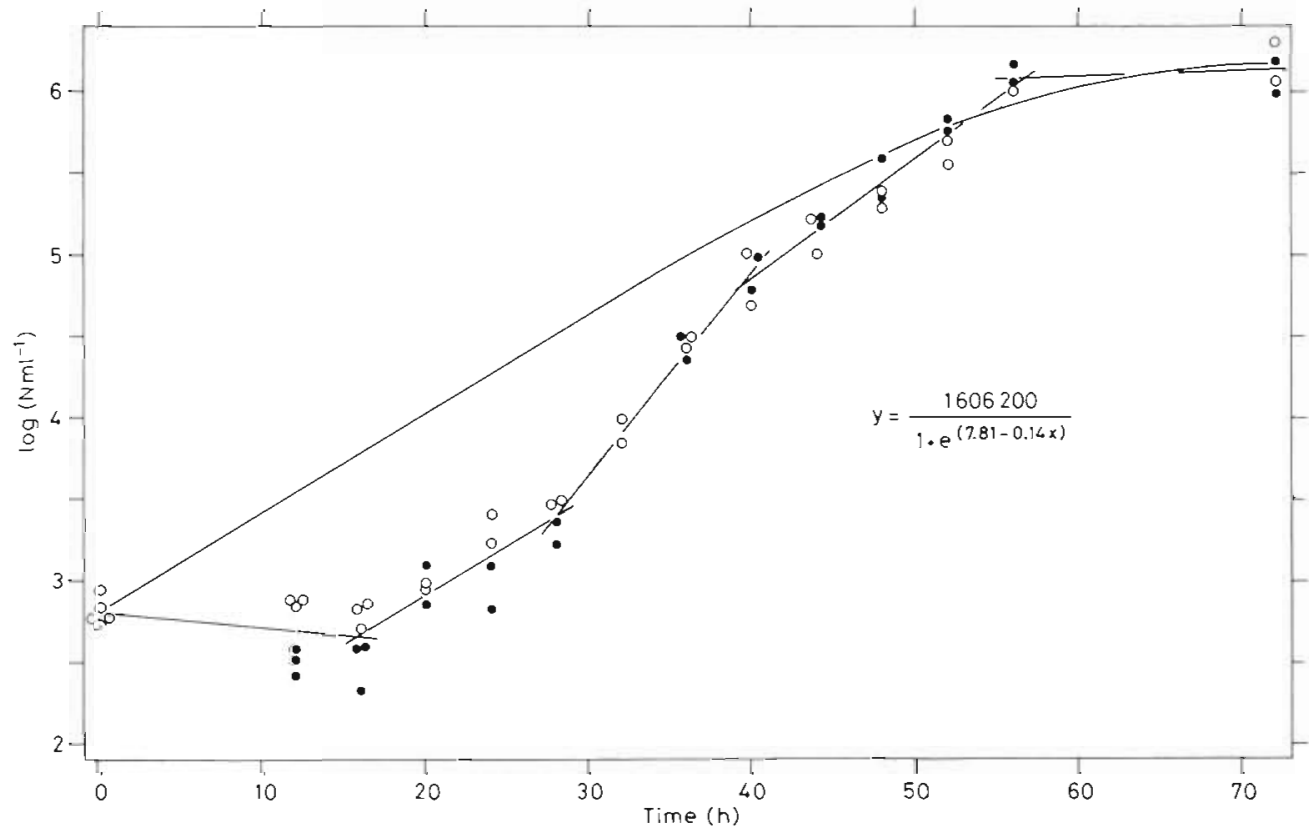

Fig. 12. Development of bacterial densities as a function of ambient Hg concentration. Controls: open circles; $10 \mu g \mathrm{l}^{-1} \mathrm{Hg}: \mathrm{closed}$ circles. Straight lines: rates of growth. Logistic curve shows growth lacking a stationary phase

which represent the basis for effect evaluation. Possible adsorption of amino acids on glass walls, if occurring at all, has only minor effects. This is evident from experiments, in which sterilized sea water was used instead of sea water of low bacterial activity. In these tests, amino-acid concentrations remain unchanged (Siebers and Ehlers, 1979, their Figs. 4, 5). Unchanged amino-acid levels in sterilized sea water support our assumption that no heterotrophic bacteria successfully competing with originally present marine populations had entered the unstoppered Erlenmeyer flasks via air. We conclude this also from a nearly identical development of replicate populations, indicated by the small variability of time-dependent amino-acid concentrations. In case of contaminaton a higher variability would have resulted.

Concerning the transferability of our results to conditions prevailing in the natural habitat, it may be 


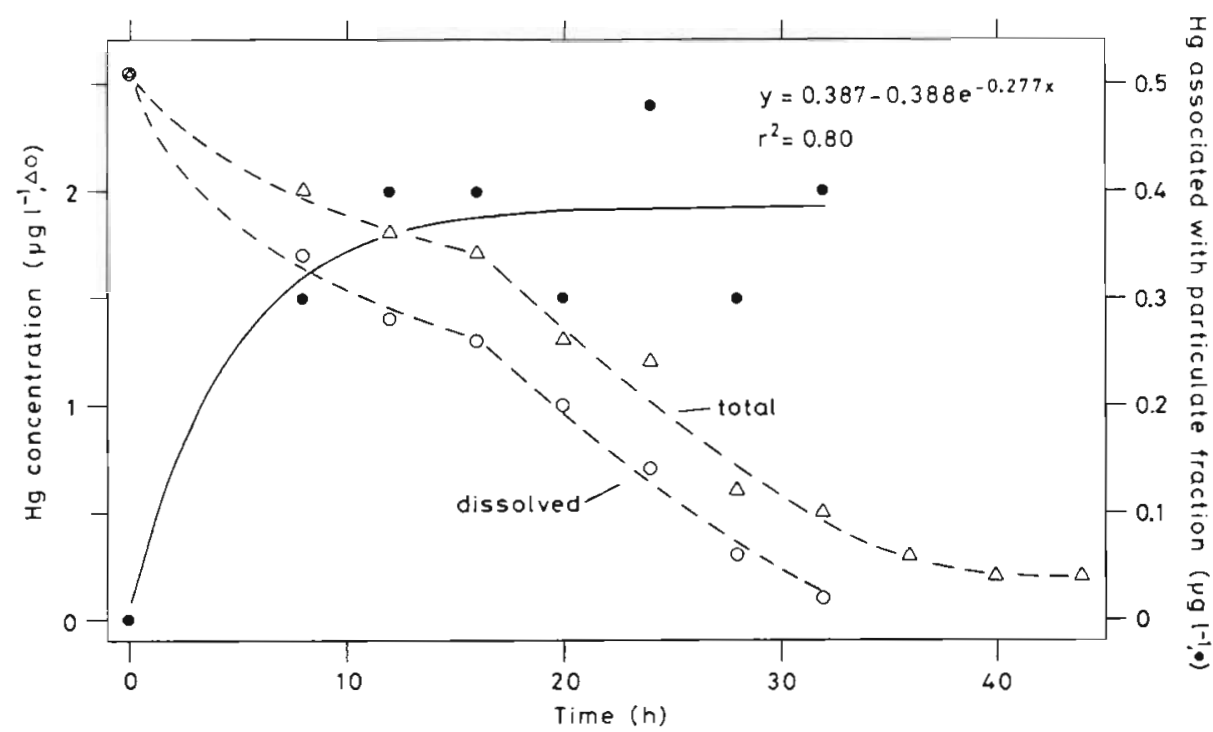

Fig. 13. Total, dissolved and particulate $\mathrm{Hg}$ as a function of time. Initial concentration of dissolved $\mathrm{Hg}_{\mathrm{g}}$ was $2.5 \mu \mathrm{g} \mathrm{I}^{-1}$. Same experiment as in Fig. 9

argued that the tests were performed with small volumes of sea water under constant conditions, i. e. in a rather artificial environment. In this context it may be mentioned that Hollibaugh (1979) obtained closely corresponding results on the dynamics of coastal bacterio-plankton communities from the outer Halifax Harbour, Nova Scotia (Canada) after addition of $10 \mu \mathrm{M}$ of several individual amino acids

\section{Lag Phases}

In all tests bacterial communities exhibited initial lag phases - periods, during which no measurable amino-acid absorption occurred. The few heterotrophic bacteria found in sea water of low bacterial activity - used as bacterial source in all experiments had previously been exposed to absolute minimum conditions for months. Bacteria fall to dormancy when no suitable nutrients are available. During dormancy uptake proceeds so slowly that no measurable aminoacid absorption can be observed. Dormancy can last very long and is ultimately followed by cell death. In sea water stored for 5 y in closed 25-1 glass bottles in the dark at $15^{\circ} \mathrm{C}$ we found about 30 heterotrophic bacteria $\mathrm{ml}^{-1}$

Shortly after suitable nutrients become available, bacterial populations respond through metabolic adaptation or activation involving the synthesis of inducible uptake apparatus (e. g. Hollibaugh, 1979). The first step in the activation process is recognition of the nutrients and their chemical nature leading to a modification of uptake capacities specifically designed to absorb only the nutrient offered or, in the case of less pronounced specificity, also substances of similar chemical nature. Even when the individual or the population is in a dormant state, the capacity for recognition must be kept functioning, a conditio sine qua non for the successful return to activity. Whether the increased amino-acid absorption following the initial stationary phase results from an induced decrease in affinity only or from an enlargement of the number of uptake sites also, has not been analyzed. With respect to the finding that uptake precedes multiplication (Figs, 11, 12), we agree with Hollibaugh (1979), who obtained corresponding results based on measurements of amino acids and ATP: the increased aminoacid uptake results from induced capacities in a relatively unchanged number of bacteria rather than from an increased number of bacterial cells due to multiplication.

\section{Sensitive and Tolerant Bacteria}

Considering the susceptibility of bacterial aminoacid uptake to the presence of mercury in sea water, we found an unexpected sensitivity; this became obvious from time lags for $50 \%$ amino-acid uptake significantly differing between unpolluted controls and populations exposed to $0.625 \mu \mathrm{g} \mathrm{^{-1 }} \mathrm{Hg}$. Bacteria thus belong to the most sensitive organisms tested in this respect - a not surprising finding, when taking into account that short-term static test procedures yield biological responses which integrate the effects on all susceptible functions involved over a period of many generations.

That uptake differs significantly between com- 
munities exposed to 0.625 and the neighbouring levels of 0 and $1.25 \mu \mathrm{g}^{-1} \mathrm{Hg}$ may be due to inhibition of amino-acid transport and related processes in all initially present bacterial cells, without directly affecting survival and multiplication. At higher $\mathrm{Hg}$ concentra- tions more deleterious effects become manifest, changing the original species composition. The data in Fig. 1 suggest that effects due to different $\mathrm{Hg}$ concentrations - beginning at $5 \mu \mathrm{g} \mathrm{I}^{-1}$ and increasing by a factor of 2.5 to reach final levels of $488 \mu g \mathrm{l}^{-1} \mathrm{Hg}$ - can be clearly

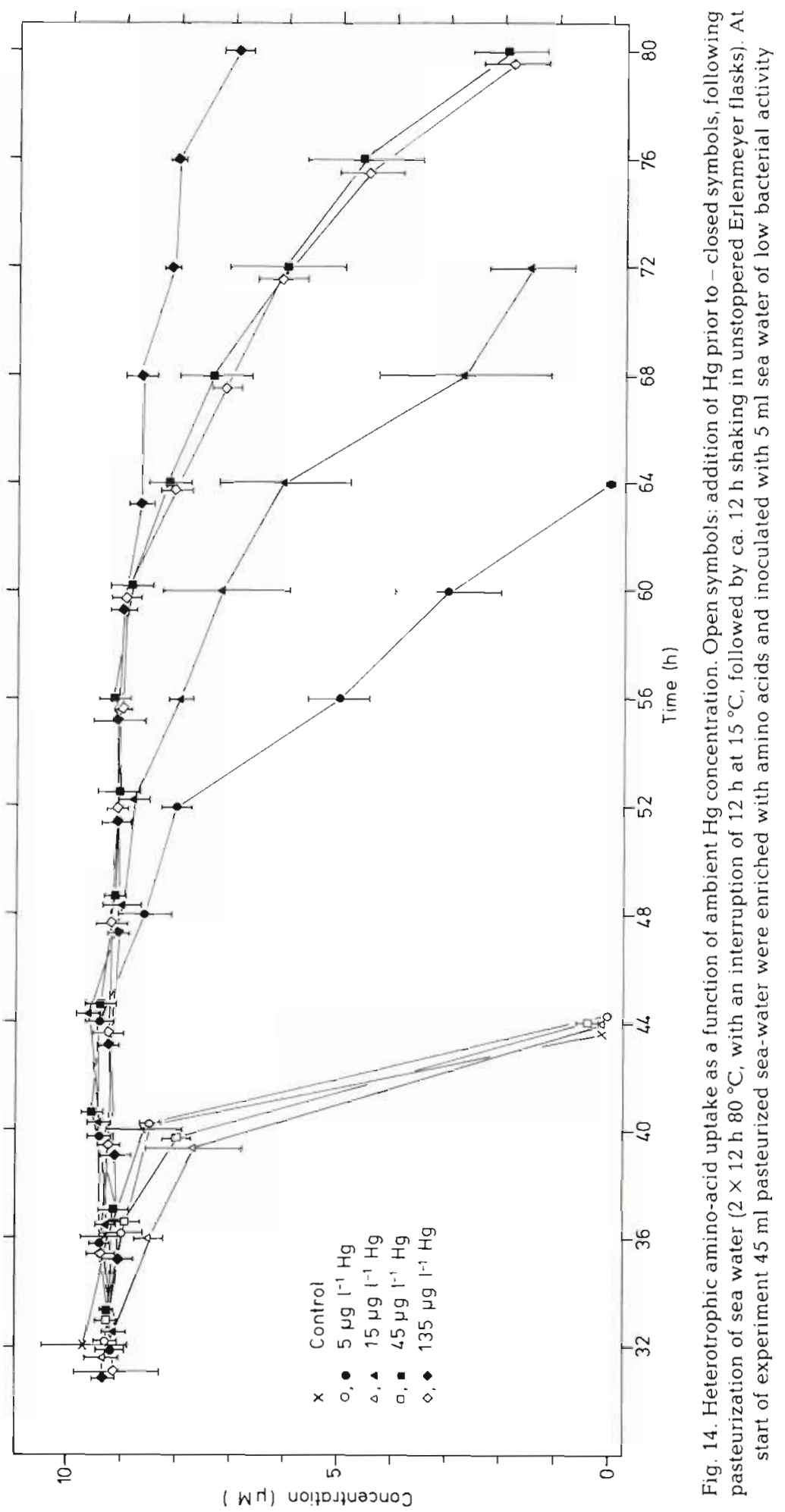


separated from each other. Uptake and bacterial activity still prevail - at reduced intensities - at the highest concentration of mercury tested. Hence it can be assumed that different species of heterotrophs present in the sea water of low bacterial activity at the start of the experiments exhibit varying tolerances to Hg. Fast uptake, observed in unpolluted controls, may result from highly active, very sensitive forms, depleting the water of nutrients so fast that uptake from less sensitive species with prolonged lag phases and reduced transport rates (Fig. 1), can scarcely contribute to the values obtained in the absence or the presence of very low $\mathrm{Hg}$ concentrations $\left(0 ; 0.625 ; 1.25 \mu \mathrm{g} \mathrm{l}^{-1} ;\right.$ Fig. 9). Tolerant forms - which may be present in the original sea water of low bacterial activity in much smaller numbers than sensitive species - manifest their presence as the only active bacteria remaining in $\mathrm{Hg}$-concentrations as high as $488 \mu \mathrm{g}^{-1}$, following inactivation of sensitive and more active species.

The assumption that more than one microbial species participates in the nutrient uptake, is supported by the biphasic relation amino-acid concentration versus time at an ambient $\mathrm{Hg}$ level of $80 \mu \mathrm{g} \mathrm{l^{-1 }}$ (Fig. 5). The data in Fig. 2 can be fitted to a single term exponential function, indicating the presence of a single species population rather than a multiple species community. However, this finding does not necessarily contradict the above-mentioned assumption that several species contribute to the strictly separable responses to increasing levels of $\mathrm{Hg}$ (Fig. 1), since in principle mixed populations may behave like single species communities (Bick, 1964).

Thormann and Weyland (1979) found among bacterial isolates, originally obtained from the brackish water of the Weser Estuary (North Sea), a variety of species which exhibited differential sensitivities to cadmium and lead. Metal-specific sensitiveness was not detected; forms with increased sensitiveness to lead also proved to be - as a rule - very sensitive to cadmium. As documented in detail by Thormann and Weyland (1979), bacterial heavy-metal tolerances tend to comprise more than one element; often metal tolerances have been shown to be concomitantly linked to reduced susceptibilities to antibiotics. These authors conclude that the heavy-metal sensitive bacteria isolated occur in the biotope in high densities. This conclusion is in sharp contrast to the finding of species which exhibit extremely high tolerances; these are present both in very low cell numbers and relative abundances. In order to isolate tolerant forms, volumes of up to $1 \mathrm{ml}$ of the undiluted sample had to be spread on the agar plates; even this resulted in relatively few colonies.

Uptake curves obtained from plotting amino-acid concentrations versus time - which enabled us to quantify responses to different concentrations of mercury and to establish dose/response relations for bioassay procedures - are therefore regarded to be based on 3 biological features, which cannot be separated strictly from each other on the basis of the experiments described. These features are: (1) Different bacterial species with differing degrees of tolerance are present in natural bacterial communities. The bacteria comprise high relative abundances of sensitive forms and low relative abundances of tolerant species. (2) At the lowest concentrations tested mercury may have suppressed uptake without causing further observable effects on individuals or populations. (3) High tolerance to $\mathrm{Hg}$ is accompanied by reduced uptake rates and prolonged lag phases, especially at higher ambient pollutant concentrations.

\section{Ecological Aspects}

Compared to the lowest Hg levels tested in our experiments, oceanic background concentrations of a few $n g \mathrm{l}^{-1}$ are much lower and not harmful to bacterid. Higher levels of dissolved $\mathrm{Hg}\left(0.03-0.1 \mu \mathrm{g} \mathrm{l^{-1 }}\right)$ may occur in polluted estuaries (Lindberg et al., 1975; Davies and Pirie, 1978; So, 1979). Here, local inhibition of bacteria may occur (Goulder et al., 1978). Hollibaugh (1979) observed retardation of arginine uptake similar to that due to $\mathrm{Hg}$ effects in our experiments in natural bacterial communities after the temperature had been lowered from $25^{\circ} \mathrm{C}$ to $3-5^{\circ} \mathrm{C}$.

\section{Bioassays}

Various biological responses have been used to analyze water quality, among them survival (Anderson and Abdelghani, 1980), growth (Bringmann and Kühn, 1979), ATP (Kennicut, 1980), oxygen uptake (Plötz, 1974), and nutrient absorption (Albright and Wilson, 1974; Gillespie and Vaccaro, 1978; Bossard and Gächter, 1979; Sayler et al., 1979)

When sea-water samples are to be bioassayed for toxic properties by means of the sensitive bacterial test employed in our investigation, transport, storage and freeing of sea water from originally present bacteria cannot be avoided. These manipulative steps result in loss of $\mathrm{Hg}$ This fact prevents us from suggesting monitoring of amino-acid uptake by bacterioplankton as a routine method of bioassaying sea-water samples

Acknowledgements. We thank M. Bartel, H. Fischer, Dr W Gunkel, R. Kleinfeld, K.-W Klings, Dr. K. Klockner, J. Marschall, and J. Willfuhr for technical assistance, provision of methods, manuscript preparation, drawing of figures, and collection and transport of sea-water samples. 


\section{LITERATURE CITED}

Albright, L. J., Wilson, E. M. (1974). Sublethal effects of several metallic salts - organic compounds combinations upon the heterotrophic microflora of a natural water Wat. Res. 8: 101-105

Andersen, A. C., Abdelghani, A. A. (1980). Toxıcity of selected arsenical compounds in short term bacterial bioassays. Bull. Environm. Toxicol. 24: 124-127

Bick, H. (1964). Die Sukzession der Organismen bei der Selbstreinigung von organisch verunreinigtem Wasser unter verschiedenen Milieubedıngungen, Hang-Druck, Düsseldorf

Bohling, H. (1972). Gelöste Aminosauren in Oberflächengewasser der Nordsee bei Helgoland: Konzentrationsveränderungen im Sommer 1970. Mar Biol. 16: 281-289

Bossard, P., Gächter, R. (1979). MELIMEX, an experimental heavy metal pollution study: Effects of increased heavy metal load on uptake of glucose by natural planktonic communities. Schweiz. Z. Hydrol. 41: 261-270

Bringmann, G., Kühn, R. (1979). Vergleich der toxischen Grenzkonzentrationen wassergefährdender Stoffe gegen Bakterien, Algen und Protozoen im Zellvermehrungshemmtest. Haustechnik, Bauphysik, Umwelttechnik 100: 249-252

Calabrese, A., Collier, R. S., Nelson, D. A., Maclnnes, I. R. (1973). The toxicity of heavy metals to embryos of the American oyster Crassostrea virginica. Mar Biol. 18: $162-166$

Cardwell, R. D., Woelke, C. E., Carr, M. J., Sanborn, E. W (1977). Evaluation of the efficacy of sulfite pulpmill pollution abatement using oyster larvae. In: Mayer, F. L. Hamenink, J. L. (eds.) Aquatic toxicology and hazard evaluation. ASTM Spec. Techn. Publ. No. 634. American Society for Testing and Materials, Philadelphia, pp. 281-295

Davies, J. M., Pirie, J. M. (1978). The mussel Mytilus edulis as a bio-assay organism for mercury in seawater Mar Poll. Bull. 9: 128-132

Dawson, R., Pritchard, R. G. (1978). The determination of $u$ amino acids in sea water using a fluorimetric analiser Mar Chem. 6: 27-40

Gillespie, P. A., Vaccaro, R. F. (1978). A bacterial bioassay for measuring the copper - chelation capacity of seawater Limnol. Oceanogr 23: 543-548

Goulder, R., Blanchard, A. S., Sanderson, P. L., Wright, B. (1978). Relationships between heterotrophic bacteria and pollution in an industrialized estuary. Wat. Res. 14: $591-601$

Gunkel, W., Rheinheimer, G. (1968). Bakterien. In: Schlieper, C. (ed.) Methoden der meeresbiologischen Forschung Gustav Fischer Verlag, Jena, pp. 142-157

Harms, U. (1979). Analytical procedures for the determination of copper, zinc, cadmium, lead, and total mercury in organic material. In: Guidelines for the Baltic monitorıng program for the first stage. Ed. by the scientific expert of the interim Baltic marine environment protection commission, Helsinki. Annex I, March 1979, pp. 93-107

Hollibaugh, J. T (1979). Metabolic adaptation in natural bacterial populations supplemented with selected amino acids. Estuar. coast. mar. Sci. 9: 215-230

Jensen, A., Rystad, B., Melsom, S. (1974). Heavy metal tolerance of marine phytoplankton. I. The tolerance of three algal species to zinc in coastal waters. J. exp. mar Biol. Ecol. 15: 145-157
Karbe, L. (1972). Marine Hydroiden als Testorganismen zur Prüfung der Toxizität von Abwasserstoffen. Die Wirkung von Schwermetallen auf Kolonien von Eirene viridula. Mar. Biol. 12: 316-328

Kennicut, M. C. (1980). ATP as an indicator of toxicity. Wat. Res. 14: 325-328

Kobayashi, N. (1971). Fertilized sea urchin eggs as an indicatory material for marine pollution bioassay, preliminary experiments. Seto Mar. Biol. Lab. 18 (6): 379-406

Kurtz, D. A. (1977). Adsorption of PCBs and DDTs on membrane filters - a new analysis method. Bull. environ. Toxicol. 17. 391-398

Lindberg, S. E., Andren, A. W., Harriss, R. C. (1975) Geochemistry of mercury in the estuarine environment. In: Cronin, L. E. (ed.) Estuarine Research. Academic Press, New York, pp. 64-107

North, B. B. (1975). Primary amines in California coastal waters: Utilization by phytoplankton. Limnol. Oceanogr 20: $20-27$

Okubo, K., Okubo, I (1962). Study on the bioassay method for the evaluation of water pollution. II. Use of fertilized eggs of sea urchins and bivalves. Bull. Tokai Reg. Fish. Res. Lab. 32: 131-140

Olafsson, J. (1974). Determination of nanogram quantities of mercury in sea-water Analytica chim. Acta 68: 207-211

Plötz, J. (1974). Ein einfaches Verfahren zur Bestimmung der Gesamttoxizität von Wasser- und Abwasserproben für Bakterien. Dtsch. Gewässerkundl. Mitt. 18: 77-79

Reed, L. J., Muench, H. (1938). A simple method of estimating fifty per cent endpoints. Am. J. Hyg. 27: 493-497

Sayler, G. S., Lund, L. C., Shiaris, M. P., Sherrill, T W. Perkins, R. E. (1979). Comparative effects of Aroclor 1254 (polychlorinated biphenyls) and phenanthrene on glucose uptake by freshwater microbial populations. Appl. Environm. Microbiol. 37: 878-885

Siebers, D. (1979). Transintegumentary uptake of dissolved amino acids in the sea star Asterias rubens. A reassessment of its nutritional role with special reference to the significance of heterotrophic bacteria. Mar Ecol. Prog. Ser. 1: 169-177

Siebers, D., Ehlers, U. (1979). Heavy metal action on transintegumentary absorption of glycine in two annelid species. Mar Biol. 50: 175-179

So, C. L. (1979). Mercury-water interactions in the estuarıne environment. Mar Poll. Bull. 10: 334-337

Stebbing, A. R. D., Ákesson, B., Calabrese, A., Gentile, J. M., Jensen, A., Lloyd, R. (1980). The role of bioassays in marine pollution monitoring. Rapp. P.-v. Réun. Cons. int. Explor. Mer 127: 322-332

Stephens, G. C. (1975). Uptake of naturally occurring primary amines by marine annelids. Biol. Bull. mar biol. Lab., Woods Hole 149: 397-407

Thormann, D., Weyland, H. (1979). Beziehungen zwischen Brackwasser- und Meeresbakterien und der wachstumshemmenden Wirkung von Cadmium und Blei. Veröff. Inst. Meeresforsch. Bremerh. 17: 163-188

Udenfried, S., Stein, S., Böhlen, P., Dairman, W., Leimgruber, W., Weigele, M. (1972). Fluorescamine: A reagent for assay of amino acids, peptides, proteins, and primary amines in the picomole range. Science, N. Y 178: 871-872

Woelke, C. E. (1972). Development of a receiving water quality bioassay criterion based on the 48-h Pacific oyster (Crassostrea gigas) embryo. Washington Department of Fisheries, Techn. Rep. 9: 1-13

Wold, S. (1974). Spline functions in data analysis. Technometrics 16: 1-11

This paper was presented by Dr. D. Siebers; it was accepted for printing on June 25, 1981 